Erratum

\title{
Erratum to "Hyperglycemia Induces Toll-Like Receptor-2 and -4 Expression and Activity in Human Microvascular Retinal Endothelial Cells: Implications for Diabetic Retinopathy"
}

\author{
Uthra Rajamani $^{1}$ and Ishwarlal Jialal ${ }^{1,2}$ \\ ${ }^{1}$ Laboratory for Atherosclerosis and Metabolic Research, Division of Endocrinology, Diabetes and Metabolism, \\ Department of Pathology, University of California Davis Medical Center, Research Building 1, Room 3000, 4635 Second Avenue, \\ Sacramento, CA 95817, USA \\ ${ }^{2}$ Veterans Affairs Medical Center, Mather, CA 95655, USA
}

Correspondence should be addressed to Ishwarlal Jialal; ijialal@ucdavis.edu

Received 8 August 2016; Accepted 23 August 2016

Copyright (C) 2016 U. Rajamani and I. Jialal. This is an open access article distributed under the Creative Commons Attribution License, which permits unrestricted use, distribution, and reproduction in any medium, provided the original work is properly cited.

In the article titled "Hyperglycemia Induces Toll-Like Receptor-2 and -4 Expression and Activity in Human Microvascular Retinal Endothelial Cells: Implications for Diabetic Retinopathy" [1] an error occurred in Figure 2(b) during the production process. The figure should be corrected to remove the MyD88 pathway blots duplicated from Figure 2 (a). The corrected figure is as follows.

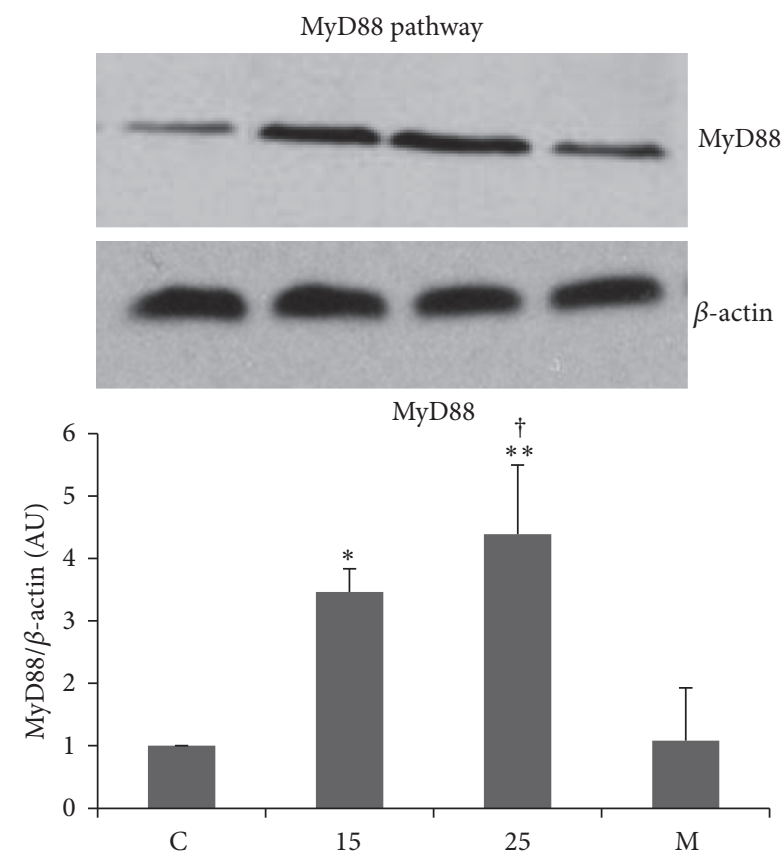

(a)

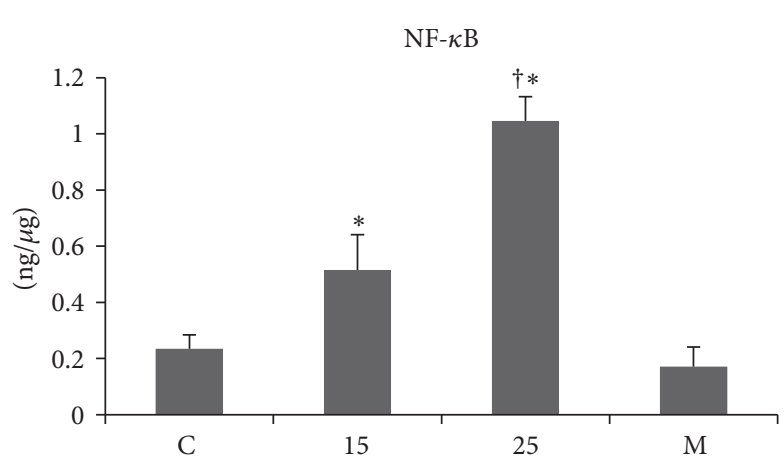

(b)

Figure 2: Continued. 


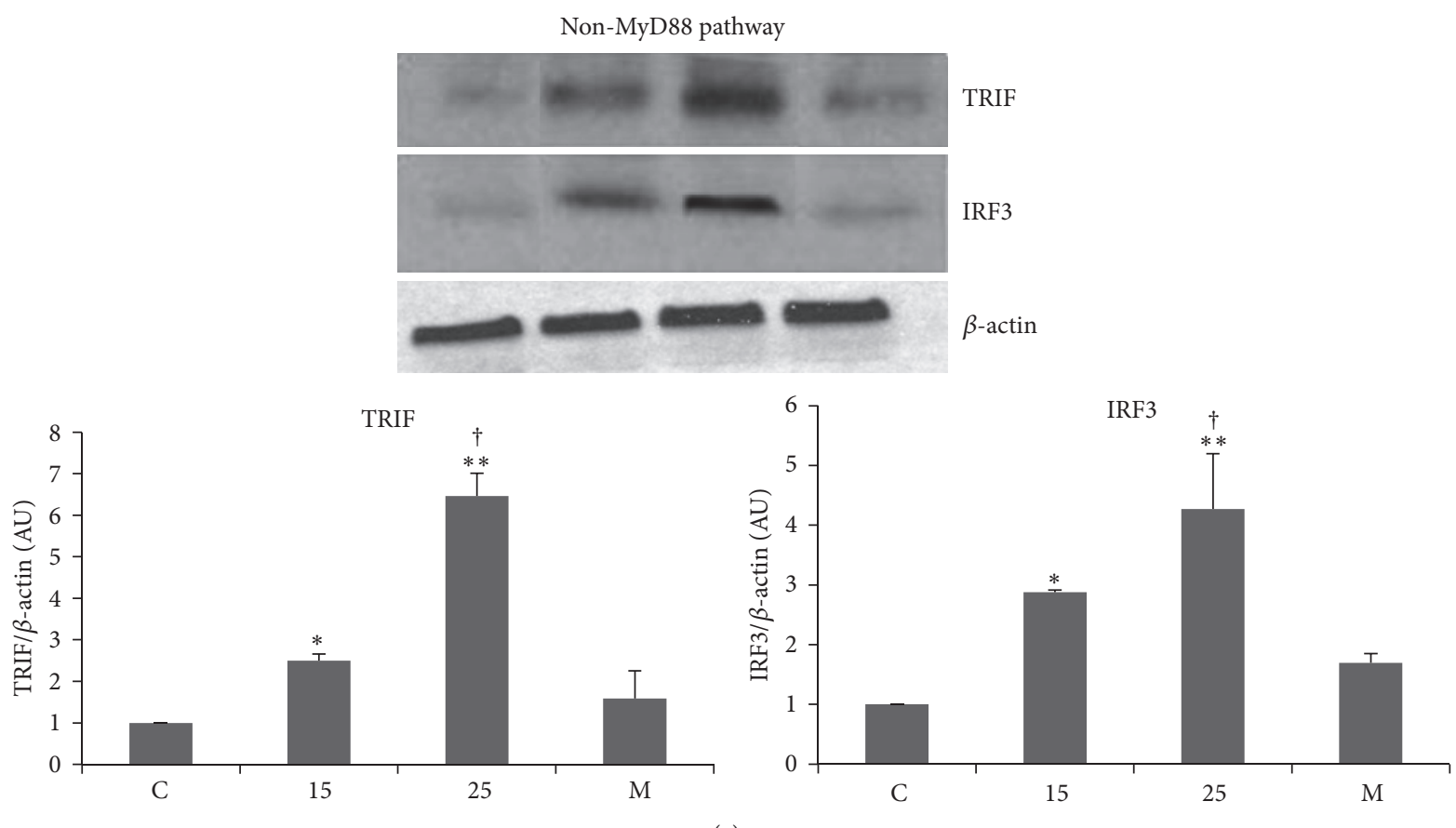

(c)

FIGURE 2: High glucose induces both MyD88 and Non-MyD88 pathways: HMVRECs were incubated and treated with 5.5, 15, and 25 mM glucose and mannitol as described in Methods and legend of Figure 1 and protein lysates were harvested. (a) Western blots showing increased MyD88 protein levels normalized against $\beta$-actin. ${ }^{*} P<0.01$ versus control and ${ }^{* *} P<0.001$ versus control. ${ }^{\dagger} P<0.05$ versus $15 \mathrm{mM}$, (b) increased nuclear p65 levels with HG treatment. ${ }^{*} P<0.001$ versus control. ${ }^{\dagger} P<0.05$ versus $15 \mathrm{mM}$, (c) representative blots showing increased TRIF and IRF3 protein levels with HG. Blots are normalized against $\beta$-actin. TRIF: ${ }^{*} P<0.05$ versus control; ${ }^{* *} P<0.001$ versus control; IRF3: ${ }^{*} P<0.01$ versus control, ${ }^{* *} P<0.001$ versus control, and ${ }^{\dagger} P<0.05$ versus $15 \mathrm{mM}$.

\section{References}

[1] U. Rajamani and I. Jialal, "Hyperglycemia induces toll-like receptor- 2 and -4 expression and activity in human microvascular retinal endothelial cells: implications for diabetic retinopathy," Journal of Diabetes Research, vol. 2014, Article ID 790902, 15 pages, 2014. 


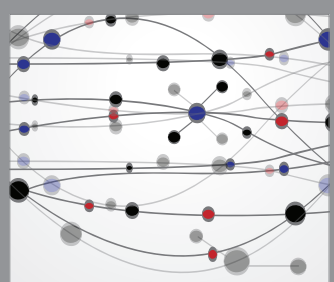

The Scientific World Journal
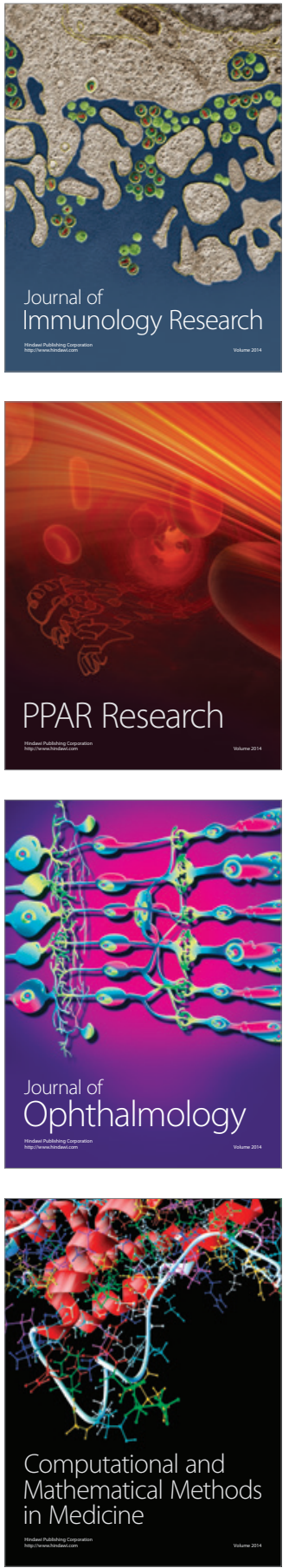

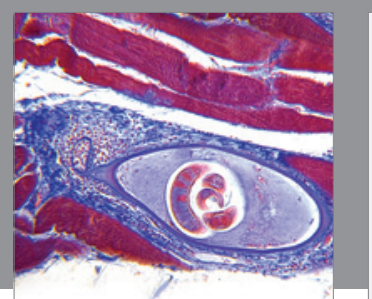

Gastroenterology Research and Practice

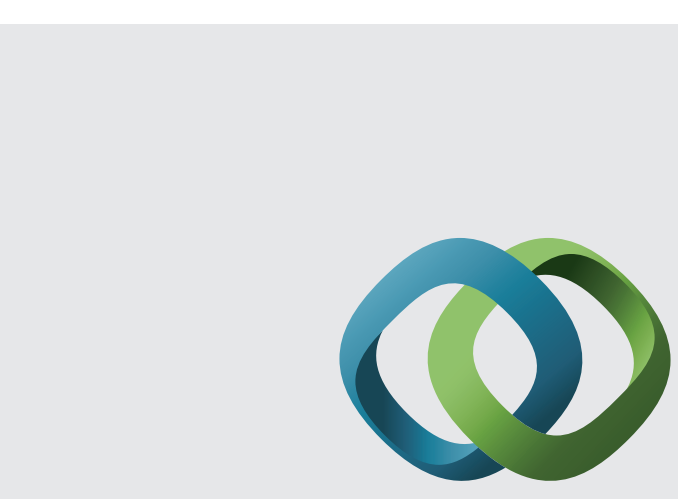

\section{Hindawi}

Submit your manuscripts at

http://www.hindawi.com
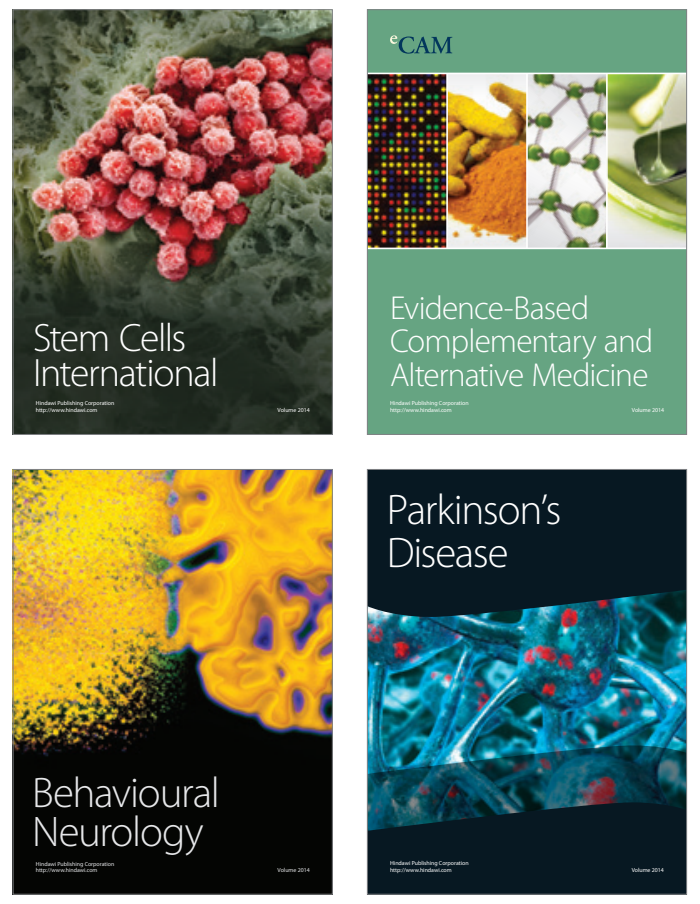
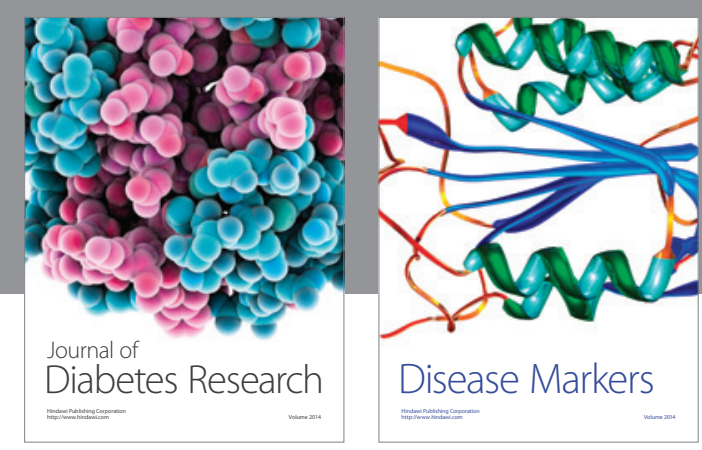

Disease Markers
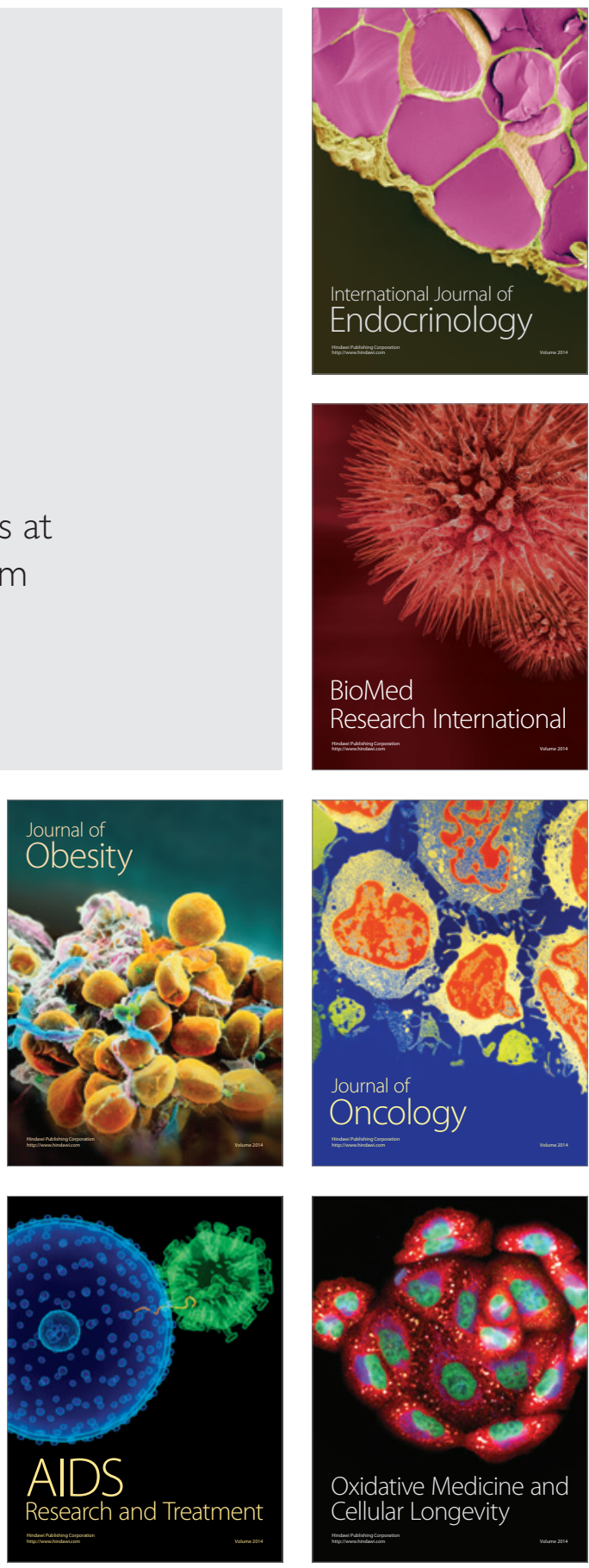